\title{
Allelopathic Activity of Cactus Used in the Foraging in the Brazilian Semi-arid
}

\author{
José Weverton Almeida Bezerra ${ }^{1,2}$, Cícero dos Santos Leandro ${ }^{1}$, Maria Daniele Pereira Rodrigues ${ }^{1}$, \\ Ana Karolina Fernandes Silva ${ }^{1}$, Danúbio Lopes da Silva ${ }^{1}$, Karina Vieiralves Linhares ${ }^{1}$, \\ Viviane Bezerra da Silva ${ }^{1}$, Janete de Souza Bezerra ${ }^{1}$, Mikael Amaro de Souza ${ }^{1}$, \\ Priscilla Augusta de Sousa Fernandes ${ }^{1}$, Jeane Dantas Sousa ${ }^{1}$, Adrielle Rodrigues Costa ${ }^{1}$, \\ Kyhara Soares Pereira ${ }^{1}$, Catarina Pereira Leite ${ }^{1} \&$ Maria Arlene Pessoa da Silva ${ }^{1}$ \\ ${ }^{1}$ Regional University of Cariri, Crato, CE, Brazil \\ ${ }^{2}$ Federal University of Pernambuco, Recife, PE, Brazil \\ Correspondence: José Weverton A. Bezerra, Federal University of Pernambuco, Recife, PE, Brazil. Tel: \\ 55-898-144-7371. E-mail: weverton.almeida@urca.br
}

Received: May 14, 2019

doi:10.5539/jas.v11n13p206
Accepted: June 22, $2019 \quad$ Online Published: August 15, 2019

URL: https://doi.org/10.5539/jas.v11n13p206

\begin{abstract}
The use of cactus for forage may cause soil contamination by allelochemicals in order to compromise the future planting or even reforestation of that site. The objective of this work was to evaluate the allelopathic action of cladodes and roots of Cereus jamacaru, Pilosocereus gounellei and Tacinga inamoena on the germination and development of Cenchrus echinatus and Calotropis procera in order to suggest actions that increase efficiency in restoration strategies. Of the species of Cactaceae mentioned above, cladodes and roots were collected for the preparation of the extracts in which two types of extracts were prepared for each organ, one treatment by hot infusion and one cold treatment. Germination Percentages (GP) and Germination Speed Index (GSI) were analyzed. In order to analyze if the extracts presented some allelopathic activity regarding the development of the seedlings, the lengths of the stem and the radicle of the recipient species were measured. The results of this research show that cacti don't significantly affect GP from seeds of other plants. However, for GSI, roots and cladodes of $T$. inamoena presented negative allelopathic activity for $C$. echinatus and C. procera, respectively. In addition to GSI, $T$. inamoena negatively affected the development of $C$. echinatus rootlets. In this way $T$. inamoena is a forage cactus that affects the development of the initial structures of surrounding plants. Thus, the exacerbation of this forage species in natural areas should be avoided, since the released allelochemicals can interfere with the ecological succession of the plant species of that environment.
\end{abstract}

Keywords: Allelochemicals, Cereus jamacaru, Pilosocereus gounellei, Tacinga inamoena

\section{Introduction}

The family Cactaceae native to the Americas has a high species richness, around 1,400 distributed in 100 genera, grouped in four subfamilies, Cactoideae, Opuntioideae, Pereskioideae and Maihuenioideae (Judd, Singer, \& Singer, 2009; Cavalcante \& Machado, 2013; Gomes, Meiado, Quirino, \& Machado, 2016). Representatives of Cactaceae tolerate water shortage by presenting specific, morphological and physiological changes, which ensure their survival in arid and semi-arid environments. Among the morphological changes, the parenchyma of the aquifer type, which presents the cytoplasm of its cells mainly occupied by water, resulting in succulent consistency (Cutter, 1986; Menezes, Taylor, \& Loiola, 2013).

Therefore, cacti have a large amount of water and organic matter, being thus used by ranchers northeastern brazilian to feed goats, sheep and cattle, especially in the dry period (Lucena et al., 2015; Nunes, Lucena, Santos, \& Albuquerque, 2015). Therefore, the farmers need to use large areas to plant the largest possible number of cacti, since the development of these plants is slow due to their metabolism CAM (Crassulaceae Acid Metabolism) (Kerbauy, 2004; Taiz \& Zeiger, 2017).

Among the species of cacti used in foraging, Cavalcanti and Resende (2006) in researches developed in the Brazilian states, Pernambuco and Bahia, found that Cereus jamacaru DC and Pilosocereus gounellei (FACWeber) Byles \& Rowley are used by $46.52 \%$ and $10.51 \%$ of the agriculturalists, respectively. While 
Tacinga inamoena (K.Schum.) N.P. Taylor \& Stuppy, is also widely used as forage for presenting flat cladodes and small spines, besides easy cultivation and propagation (Lucena et al., 2015).

Exacerbated planting of plants of a single species with allelopathic potential in the same area can considerably increase the amount of allelochemicals in that environment (Rice, 2012). These allelochemicals are derived from secondary metabolism, which can be derived from terpenes, phenolic compounds or nitrogen compounds (Weston \& Duke, 2003; Taiz \& Zeiger, 2017). Because there is an exaggerated planting of forage cacti in a single area, they may have a negative allelopathic effect and inhibit or retard the germination of other species (heterotoxicity) and even affect the growth of initial seedling structures (Willis, 2007).

Considering these aspects, the planting of a single species in a given environment can promote soil contamination by allelochemicals, in order to compromise future planting or even reforestation of the site. Thus, the present research aimed at evaluating the allelopathic action of cladodes and roots of C. jamacaru, $P$. gounellei and $T$. inamoena on the germination and development of the monocotyledon Cenchrus echinatus L. and the eudicotyledon Calotropis procera (Aiton) W.T. Aiton in order to suggest actions that increase the efficiency in strategies of restoration of environments.

\section{Materials and Methods}

\subsection{Botanical Material}

The botanical material was collected in areas of Caatinga, a dry tropical forest, in the municipalities of Crato and Quixelô, CE $\left(-06^{\circ} 24^{\prime} \mathrm{N},-39^{\circ} 27^{\prime} \mathrm{W} ;-6^{\circ} 15^{\prime \prime} \mathrm{N},-39^{\circ} 15^{\prime} \mathrm{W}\right)$ in the Northeast of Brazil, from January to June 2017 at 9:00 $\pm 30 \mathrm{hrs}$.

\subsection{Preparation of Extract}

For the preparation of the extracts were used $50 \mathrm{~g}$ of cladodes and roots of Cereus jamacaru, Pilosocereus gounellei and Tacinga inamoena. Two types of extracts were prepared for each organ, one by hot infusion (500 $\mathrm{mL}$ of distilled water at $\left.100{ }^{\circ} \mathrm{C}\right)$ and the other by cold infusion $\left(500 \mathrm{~mL}\right.$ of distilled water at $\left.25{ }^{\circ} \mathrm{C}\right)$. After 30 minutes, each was crushed for 1 minute in an industrial blender, followed by perfex ${ }^{\circledR}$ cloth filtration. They were finally subjected to centrifugation at $3000 \mathrm{rpm}$ for 10 minutes.

\subsection{Physical-Chemical Characterization}

As for the physical-chemical characterization, $\mathrm{pH}$ (Simpla, Brazil) and osmolarity (MPa) were measured. Acid extracts with $\mathrm{pH}$ less than 6.5 or alkaline $\mathrm{pH}$ values greater than 7.5 were adjusted with $0.1 \mathrm{~mol} / \mathrm{L} \mathrm{KOH}$ and $5 \%$ $\mathrm{HCl}$ for neutral bands close to 7 whereas acid or alkali extracts could interfere in the results (Macias et al., 2000).

As for osmolarity, high osmotic levels end up causing pressures, making germination of seeds impossible. To measure this parameter, an osmometer (Model PZL-1000) and $2500 \mu \mathrm{L}$ of the extracts were used. The values were obtained in $\mathrm{mOsm} / \mathrm{kg}$ and converted to $\mathrm{MPa}$. The values obtained were within the limits tolerated by the seeds.

\subsection{Allelopathic Activity}

To verify allelopathic action bioassays were performed consisting of four treatments: cladodes extract at $100{ }^{\circ} \mathrm{C}$ (EQC) cladodes extract at $25^{\circ} \mathrm{C}(\mathrm{EFC})$, roots extract at $100{ }^{\circ} \mathrm{C}(\mathrm{EQR})$, root extract $25{ }^{\circ} \mathrm{C}(\mathrm{EFR})$ and a control group for which only distilled water was used. The treatments consisted of 4 replicates with 25 seeds of $C$. procera and $C$. echinatus totaling 100 seeds per treatment. The bioassays were mounted on Petri dishes containing two sheets of germitest paper moistened with $3 \mathrm{~mL}$ of extract. The experiment was conducted in a B.O.D (Quimis, Brazil) type germination chamber with a temperature of $25^{\circ} \mathrm{C}$ and a light/dark cycle of 12 hours for 5 days. The germinated seeds were counted every 24 hours, considering the germination of the seeds that had a root length equal to or greater than $2 \mathrm{~mm}$.

\subsection{Variables Analyzed}

\subsubsection{Germination Percentage (GP)}

To calculate the percentage of germination, the following formula was used:

$$
\mathrm{GP}=(\mathrm{N} / \mathrm{Nt}) \times 100
$$

Where, $\mathrm{N}$ refers to the number of seeds germinated and $\mathrm{Nt}$ refers to the total number of seeds sown.

\subsubsection{Germination Speed Index (GSI)}

The Germination Speed Index (GSI) evaluates the speed of occupation of a given plant species in a given environment (Ferreira \& Borghetti, 2004). To determine the GSI, the formula of Maguire (1962) was adopted: 


$$
G S I=\left(E^{1} / N^{1}+E^{2} / N^{2}+\ldots E^{n} / N^{n}\right)
$$

Where, $\mathrm{E}^{1}, \mathrm{E}^{2}$ and $\mathrm{E}^{\mathrm{n}}$ is the number of emerged normal seedlings computed at the first, second and last counts, respectively, and $\mathrm{N}^{1}, \mathrm{~N}^{2}$ and $\mathrm{N}^{\mathrm{n}}$, is the number of days from sowing to the first, second and last count.

\subsubsection{Seedling Growth}

To analyze the action of the extracts on the growth of the seedlings, the lengths of the stem and radicles were measured with the help of a millimeter ruler.

\subsection{Statistical Analysis}

For statistical analysis was used GraphPadPrism program 6. For testing was performed analysis of variance (ANOVA) of a track (one way) and comparison of means by Tukey test at $5 \%$ probability.

\section{Results}

\subsection{Physico-chemical Parameters}

The extracts used in the research had slightly acidic $\mathrm{pH}(<6.5)$, and the hot extract of the cladodes of $P$. gounellei presented the lowest $\mathrm{pH}$ (4.96) and the cold extract of the roots of T. inamoena o which presented a higher $\mathrm{pH}$ (6.39). All $\mathrm{pH}$ values can be seen in Table 1. As for osmolarity, all extracts had low solute levels, and the highest osmotic pressures measured were from hot and cold extracts of T. inamoena cladodes, with a value of $-0.06 \mathrm{MPa}$. The warm extracts of the roots of $C$. jamacaru and $P$. gounellei presented the lowest osmotic pressure with a value of $-0.01 \mathrm{MPa}$ (Table 1).

Table 1. $\mathrm{pH}$ and Osmolarity of hot and cold extracts of cladodes and roots of C. jamacaru, P. gounellei and T. inamoena

\begin{tabular}{lllll}
\hline Species & Extract & $\mathbf{p H}$ measured & $\mathbf{p H}$ adjusted & Osmolarity (MPa) \\
\hline \multirow{4}{*}{ Cereus jamacaru } & EQC & 5.06 & 6.59 & -0.04 \\
& EFC & 5.18 & 6.98 & -0.03 \\
& EQR & 5.78 & 5.81 & -0.01 \\
\multirow{3}{*}{ Pilosocereus gounellei $i$} & EFR & 5.89 & 7.21 & -0.04 \\
& EQC & 4.96 & 6.54 & -0.04 \\
& EFC & 5.11 & 7.25 & -0.03 \\
& EQR & 5.64 & 6.57 & -0.01 \\
\multirow{2}{*}{ Tacinga inamoena } & EFR & 5.62 & 7.30 & -0.03 \\
& EQC & 5.02 & 6.52 & -0.06 \\
& EFC & 5.08 & 6.74 & -0.06 \\
& EQR & 6.39 & 6.50 & -0.04 \\
& EFR & 5.95 & 7.49 & -0.03 \\
\hline
\end{tabular}

Note. Legend: EQC: Cladodes hot extract; EFC: Cold extract of cladodes; EQR: Hot root extract; EFR: Cold extract from the roots.

\subsection{Germination Percentage (GP)}

Cladodes and roots extracts of $C$. jamacaru, $P$. gounellei and T. inamoena (donor species) did not significantly affect the percentage of germination of $C$. echinatus and $C$. procera seeds since the results did not differ statistically from the control group as can be observed in Figure 1. Thus, it is inferred that the allelochemicals produced by the donor species do not interfere in the germination of the seeds of the recipient species. 


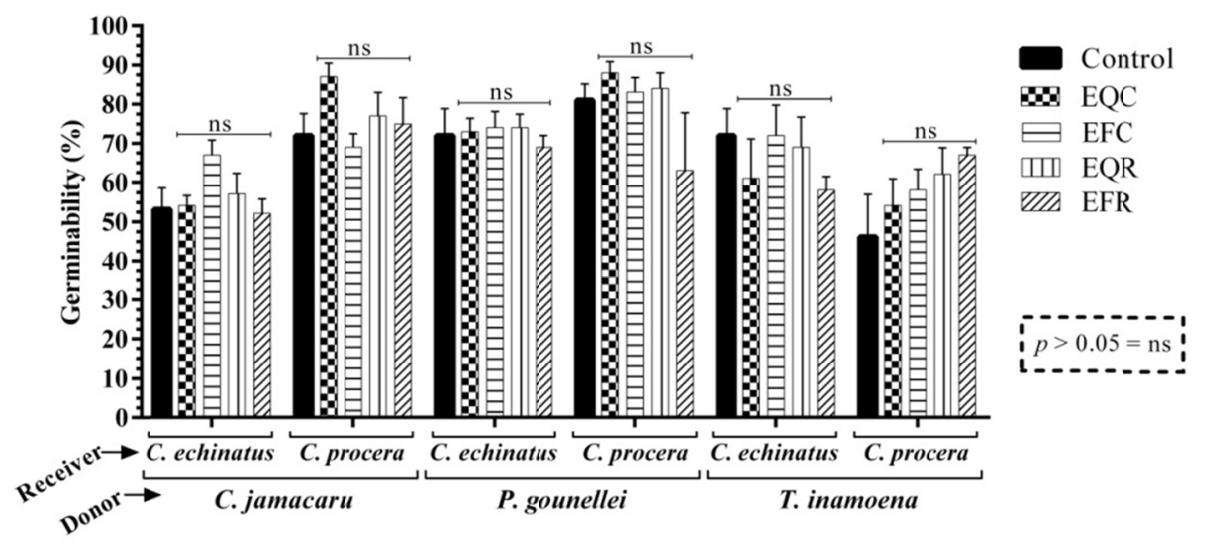

Figure 1. Germination percentage of seed of Cenchrus echinatus and Calotropis procera in touch to the extracts of Cereus jamacaru, Pilosocereus gounellei and Tacinga inamoena. Analysis of variance (ANOVA) One-way. Mean ( \pm standard deviation). Ns: no statistical significance when compared to control. EQC: Cladodes hot extract; EFC: Cold extract of cladodes; EQR: Hot root extract; EFR: Cold extract from the roots

\subsection{Germination Speed Index (GSI)}

The seeds of $C$. echinatus submitted to the cold extract of the cladodes of $C$. jamacaru showed an increase in GSI, showing a positive allelopathic action, the GSI value was $11.34 \pm 2.63$, and differed statistically from the control group which was $6.55 \pm 2.17$. While the cold extract of the roots of $T$. inamoena presented negative allelopathic activity presenting an index of 7.57 \pm 2.33 , differing significantly from the control group, which was 15.58 \pm 2.19 . However, P. gounellei extracts would not interfere with the GSI of the recipient species (Table 2).

Table 2. Germination speed index (GSI) of the seeds of Cenchrus echinatus and Calotropis procera submitted to extracts of Cereus jamacaru, Pilosocereus gounellei and Tacinga inamoena

\begin{tabular}{llllllll}
\hline \multirow{2}{*}{ Extract } & \multicolumn{3}{c}{ Cenchrus echinatus } & & \multicolumn{3}{c}{ Calotropis procera } \\
\cline { 2 - 4 } & C. jamacaru & P. gounellei & T. inamoena & & C. jamacaru & P. gounellei & T. inamoena \\
\hline EQC & $8.63 \pm 1.26 \mathrm{ab}$ & $17.05 \pm 1.56 \mathrm{a}$ & $11.43 \pm 3.85 \mathrm{ab}$ & & $7.53 \pm 0.91 \mathrm{a}$ & $8.15 \pm 1.07 \mathrm{a}$ & $3.67 \pm 0.93 \mathrm{~b}$ \\
$\mathrm{EFC}$ & $11.34 \pm 2.63 \mathrm{~b}$ & $17.63 \pm 1.85 \mathrm{a}$ & $14.05 \pm 4.09 \mathrm{ab}$ & & $5.16 \pm 1.32 \mathrm{~b}$ & $7.56 \pm 0.96 \mathrm{a}$ & $4.50 \pm 0.95 \mathrm{ab}$ \\
$\mathrm{EQR}$ & $7.12 \pm 2.18 \mathrm{ab}$ & $16.98 \pm 2.05 \mathrm{a}$ & $10.89 \pm 2.69 \mathrm{ab}$ & & $5.15 \pm 0.79 \mathrm{~b}$ & $8.29 \pm 0.76 \mathrm{a}$ & $4.13 \pm 1.11 \mathrm{ab}$ \\
EFR & $8.32 \pm 0.97 \mathrm{ab}$ & $15.91 \pm 1.50 \mathrm{a}$ & $7.57 \pm 2.33 \mathrm{~b}$ & & $5.01 \pm 1.37 \mathrm{~b}$ & $6.58 \pm 2.94 \mathrm{a}$ & $4.57 \pm 0.30 \mathrm{ab}$ \\
\hdashline Control $\left(\mathrm{H}_{2} \mathrm{O}\right)$ & $6.55 \pm 2.17 \mathrm{a}$ & $15.58 \pm 2.19 \mathrm{a}$ & $15.58 \pm 2.19 \mathrm{a}$ & & $5.32 \pm 0.85 \mathrm{ab}$ & $9.83 \pm 1.16 \mathrm{a}$ & $6.35 \pm 1.62 \mathrm{a}$ \\
\hline
\end{tabular}

Note. Legend: EQC: Cladodes hot extract; EFC: Cold extract of cladodes; EQR: Hot root extract; EFR: Cold extract from the roots. Means followed by the same column letter do not differ from each other at 5\% probability, by the Tukey test.

The GSI of the seeds of $C$. procera submitted to extracts of the cladodes or roots of $C$. jamacaru and $P$. gounellei was not affected when compared to the control group. However, the hot extract of $T$. inamoena negatively affected the GSI of $C$. procera seeds as can be seen in Table 2.

\subsection{Seedling Growth}

Extracts of $C$. jamacaru, $P$. gounellei and T. inamoena did not significantly affect $C$. echinatus stem growth (Figure 2). In relation to the radicle growth, a negative allelopathic effect of the seedlings submitted to the hot extract of the roots of $C$. jamacaru and to the hot and cold extracts of $T$. inamoena roots and cladodes were observed in relation to the control group as can be seen in Figure 2. 


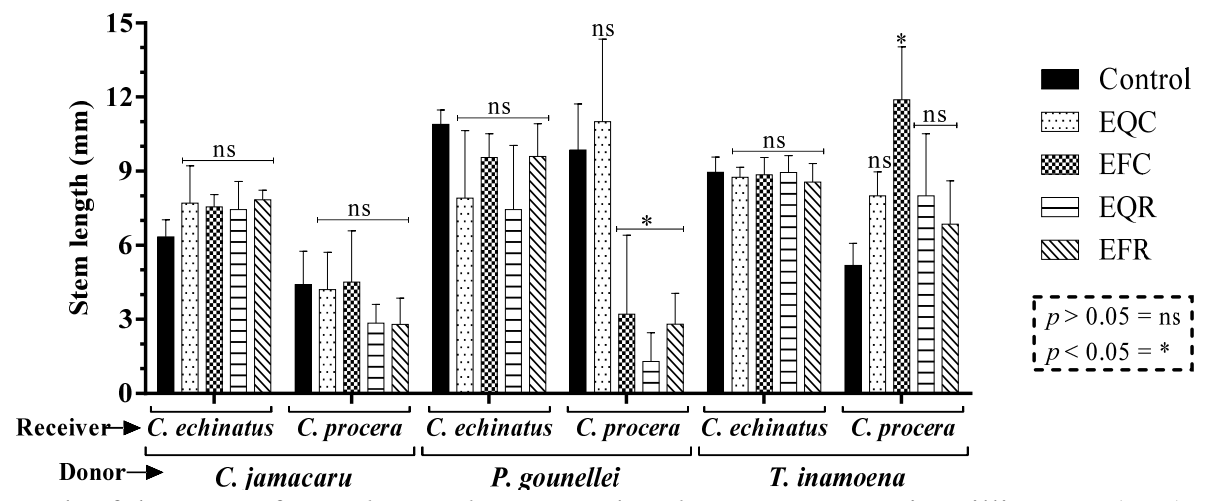

Figure 2. Growth of the stem of Cenchrus echinatus and Calotropis procera in millimeters (mm) submitted to extracts of Cereus jamacaru, Pilosocereus gounellei and Tacinga inamoena. Analysis of variance (ANOVA) One-way. Mean ( \pm standard deviation). Equal letters do not differ statistically. Legend: EQC: Cladodes hot extract; EFC: Cold extract of cladodes; EQR: Hot root extract; EFR: Cold extract from the roots

For $C$. procera seedlings compared with the control group, it was found that the growth of stems of the seedlings subjected to the extracts, the cladodes of cold and hot and cold root of $P$. gounellei were adversely affected. Whereas the cold extract of $T$. inamoena cladodium positively affected the growth of the host cells. Extracts of $C$. jamacaru did not interfere in the growth of said structure. These results can be seen in Figure 3.

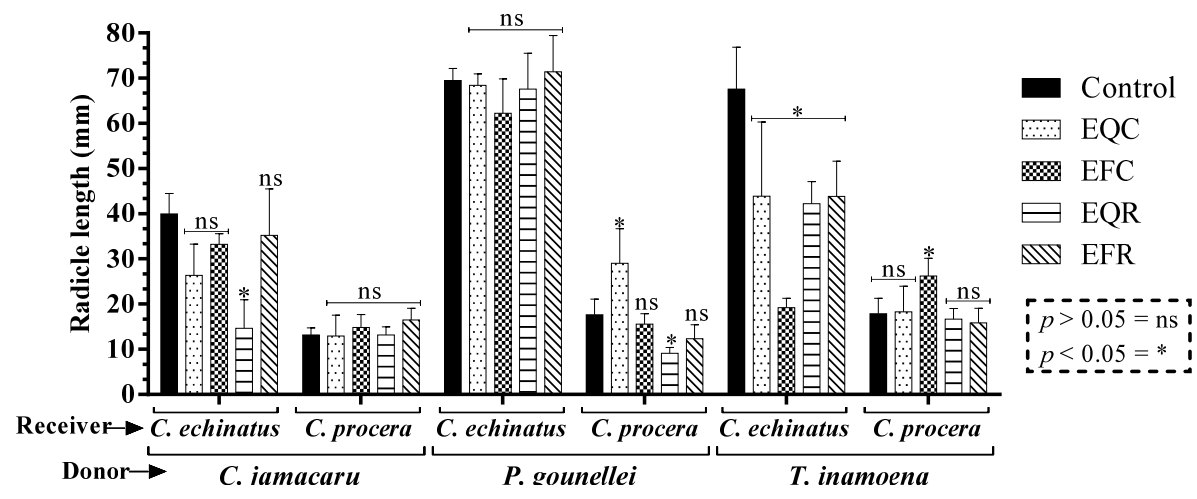

Figure 3. Growth of the roots of Cenchrus echinatus in millimeters (mm) submitted to extracts of Cereus jamacaru, Pilosocereus gounellei and Tacinga inamoena. Analysis of variance (ANOVA) One-way. Mean ( \pm standard deviation). Equal letters do not differ statistically. Legend: EQC: Cladodes hot extract; EFC: Cold extract of cladodes; EQR: Hot root extract; EFR: Cold extract from the roots

In relation to the growth of the radicle of Calotropis procera, it was observed in comparison with the control group that the hot extract of the roots of $P$. gounellei negatively affected the growth of the radicles while the hot extract of the cladodes affected in a positive way. The cold extract of the cladodes of $T$. inamoena also promoted the growth of the radicles of the recipient species, thus presenting a positive allelopathic effect. Extracts of $C$. jamacaru did not interfere with the growth of said structure (Figure 3).

\section{Discussion}

C. jamacaru, $P$. gounellei and T. inamoena species widely used as fodder, release allelochemicals that may interfere with the growth of seedlings surrounding these plants. In addition to negatively affecting the speed of germination of seeds of other species, such as weeds (Cenchrus echinatus and Calotropis procera) used as recipients in the present research, they do not interfere with the amount of germinated seeds. Corroborating well with results obtained by Ferreira and Aquila (2000), which state that the allelopathic action is not always manifested in the final germination percentage, but at the speed of germination or the growth of seedlings.

Davet (2005) reports the presence of alkaloids, belonging to the group of nitrogen compounds, and steroids of the group of terpenes in the cladodes of C. jamacaru. These groups present compounds with biological activities, among them allelopathic activity (Li, Wang, Ruan, Pan, \& Jiang, 2010). Although Davet (2005) evaluated the 
effects of the extracts of cladodes of C. jamacaru on Lactuca sativa L. (lettuce) seeds, it has reported a negative allelopathic effect on the hypocotyl and radicle growth of this species. In the present research, no significant allelopathic effects of $C$. jamacaru cladodes extracts were observed. This can be justified because $L$. sativa seeds are susceptible to allelochemical compounds even at low concentrations (Ferreira \& Aquila, 2000), whereas the seeds of $C$. echinatus and $C$. procera may be more tolerant to the presence of allelochemicals. It is worth to consider that the hot extract of $C$. jamacaru roots promoted a negative allelopathic effect on the length of $C$. echinatus, and this effect may be due to the presence and concentration of allelochemicals in the plant organ.

P. gounellei presents phenols and triterpenes in their constitution (Almeida, Silva, Amorim, Maia, \& Albuquerque 2005). In the case of phenolic compounds, some have allelopathic action such as those derived from benzoic acid and simple phenylpropanoids, such as caffeic acid. The benzoic acid derivatives, for example salicylic acid, cause disturbances in the membranes of the cells of other plants, which can affect the water balance and, consequently, inhibit the growth of the seedling (Barkosky \& Einhellig, 1993; Barkosky, Einhellig, $\&$ Butler, 2000) as was observed in the growth of the caulículo and the radicle of C. procera submitted to extracts of $P$. gounellei.

These phenolic compounds are produced from the removal of an ammonia molecule from an aromatic amino acid, phenylalanine, which then forms the cinnamic acid. This reaction is catalyzed by an enzyme called phenylalanine ammonia lyase (PAL), and among the factors that increase the activity of this enzyme is the incidence of light to which they act in phytochrome. In addition to this phenomenon caused by sunlight, another phenomena of light in ultraviolet A bands (UV-A, 320-400 nm), is the activation of some phenolic compounds, mainly furanocoumarins, leading to a high-energy electronic state (Taiz \& Zeiger, 2017). According to Li et al. (2010) and Razavi (2011), furanocoumarins have allelopathic activity in the growth of the seedlings. As the Cactaceae of this study are native to the Caatinga, a dry tropical forest, the incidence of sunlight is high so that the production of phenolic compounds becomes high.

There are reports in the literature regarding the chemical compounds present in the cladodes and roots of $T$. inamoena. However, its inhibitory action may be associated with the presence of phenolic compounds, as well as P. gounellei (Almeida et al., 2005).

The root extracts of $C$. jamacaru and $T$. inamoena promoted a negative allelopathic effect on $C$. echinatus root growth, while $P$. gounellei roots had the same effect on the roots of $C$. procera. This effect is caused by the roots of the root system from its soil fixation, in which this organ interacts with other environmental conditioning factors, such as the presence of roots of other species (Maina, Brown, \& Gersani, 2002) in order to promote a more effective establishment and avoid competition. Oliveira, Santos, Xavier, Junior, and Nascimento (2015) evaluating the competition of the root system of C. jamacaru with another Cactaceae, Melocactus bahiensis (Britton \& Rose) Luetzelb. subsp. bahiensis, found that there was a decrease in the root system of M. bahiensis subsp. bahiensis, evidencing that the roots of $C$. jamacaru interfere in the growth of another species.

\section{Conclusion}

Cereus jamacaru, $P$. gounellei and $T$. inamoena release into the environment allelochemicals by means of the roots and their cladodes which can affect the growth of the surrounding seedlings. Therefore, the exacerbation of these forage species in natural areas should be avoided, since the released allelochemicals can interfere in the ecological succession of the plant species in the different environments.

\section{References}

Barkosky, R. R., \& Einhellig, F. A. (1993). Effects of salicylic acid on plant-water relationships. Journal of Chemical Ecology, 19(2), 237-247. https://doi.org/10.1007/BF00993692

Barkosky, R. R., Einhellig, F. A., \& Butler, J. L. (2000). Caffeic acid-induced changes in plant-water relationships and photosynthesis in leafy spurge Euphorbia esula. Journal of Chemical Ecology, 26(9), 2095-2109. https://doi.org/10.1023/A:1005564315131

Cavalcante, A., Teles, M., \& Machado, M. (2013). Cactos do semiárido do Brasil: Guia ilustrado. Campina Grande, PB: INSA.

Cavalcanti, N. B., \& Resende, G. M. (2006). Consumo do mandacaru (Cereus jamacaru P. DC.) por caprinos na época da seca no semi-árido de Pernambuco. Revista Caatinga, 19(4), 402-408.

Cutter, E. G. (1986). Anatomia vegetal-Parte l: Células e tecidos (2nd ed.). São Paulo, SP: Roca.

Davet A. (2005). Estudo fitoquímico e biológico do cacto-Cereus jamacaru De Candolle, Cactaceae (Dissertação de Mestrado, Universidade Federal do Paraná, Curitiba, Brazil). Retrieved from 
https://acervodigital.ufpr.br/bitstream/handle/1884/1921/disserta\%C3\%A7\%C3\%A3o_Aline_2005.pdf?seq uence $=1$ \&isAllowed $=y$

Almeida, C. F. C. B. R., Silva, T. D. L., Amorim, E. L. C., Maia, M. D. S., \& Albuquerque, U. P. (2005). Life strategy and chemical composition as predictors of the selection of medicinal plants from the caatinga (Northeast Brazil). Journal of Arid Environments, 62(1), 127-142. https://doi.org/10.1016/j.jaridenv. 2004.09.020

Ferreira, A. G., \& Áquila, M. E. A. (2000). Alelopatia: Uma área emergente da ecofisiologia. Revista Brasileira de Fisiologia Vegetal, 12(Especial), 175-204.

Ferreira, A. G., \& Borghetti, F. (2004). Germinação: do básico ao aplicado (1st ed.). Porto Alegre, RS: Artmed.

Gomes, V. G. N., Meiado, M. V., Quirino, Z. G. M., \& Machado, I. C. (2016). Seed removal by lizards and effect of gut passage on germination in a columnar cactus of the Caatinga, a tropical dry forest in Brazil. Journal of Arid Environments, 135, 85-89. https://doi.org/10.1016/j.jaridenv.2016.08.013

Judd, W. S., Campbell, C. S., Kellogg, E. A., Stevens, P. F., \& Donoghue, M. J. (2009). Sistemática vegetal: Um enfoque filogenético (3rd ed.). Porto Alegre, RS: Artmed.

Kerbauy, G. B. (2004). Fisiologia vegetal (1st ed.). Rio de Janeiro, RJ: Guanabara Koogan.

Li, Z. H., Wang, Q., Ruan, X., Pan, C. D., \& Jiang, D. A. (2010). Phenolics and plant allelopathy. Molecules, 15(12), 8933-8952. https://doi.org/10.3390/molecules15128933

Lucena, C. M., Carvalho, T. K. N., Ribeiro, J. E. S., Quirino, Z. G., Casas, A., \& Lucena, R. F. (2015). Conhecimento botânico tradicional sobre cactáceas no semiárido do Brasil. Gaia scientia, 9(2), 77-90.

Macias, F. A., Gallindo, J. C. G., \& Molinillo, J. M. G. (2000). Plant biocommunicators: Application of allelopathic studies. Phytoconsult, 15, 137-161.

Maguire, J. D. (1962). Speed of Germination-Aid in Selection and Evaluation for Seedling Emergence and Vigor 1. Crop Science, 2(2), 176-177. https://doi.org/10.2135/cropsci1962.0011183X000200020033x

Maina, G. G., Brown, J. S., \& Gersani, M. (2002). Intra-plant versus inter-plant root competition in beans: Avoidance, resource matching or tragedy of the commons. Plant Ecology, 160(2), 235-247. https://doi.org/ 10.1023/A:1015822003011

Menezes, M. O. T. D., Taylor, N. P., \& Loiola, M. I. B. (2013). Flora of Ceará, Brazil: Cactaceae. Rodriguésia, 64(4), 757-774. https://doi.org/10.1590/S2175-78602013000400007

Nunes, A. T., Lucena, R. F. P., dos Santos, M. V. F., \& Albuquerque, U. P. (2015). Local knowledge about fodder plants in the semi-arid region of Northeastern Brazil. Journal of Ethnobiology and Ethnomedicine, 11(1), 1-12. https://doi.org/10.1186/1746-4269-11-12

Oliveira, P. A., Santos, J. M., Xavier, E. A., Junior, G. L. F., \& Nascimento, P. R. (2015). Efeito das competições inter e intraespecífica no sistema radicular e biomassa aérea e subterrânea de duas espécies de Cactaceae. Gaia Scientia, 9(2), 162-166.

Razavi, S. M. (2011). Plant coumarins as allelopathic agents. Int J Biol Chem, 5(1), 86-90. https://doi.org/ $10.3923 / \mathrm{ijbc} .2011 .86 .90$

Rice, E. L. (2012). Allelopathy (2nd ed). London, UK: Academic Press Inc.

Taiz, L., \& Zeiger, E. (2017). Fisiologia Vegetal (5th ed.). Porto Alegre, RS: Artmed.

Weston, L. A., \& Duke, S. O. (2003). Weed and crop allelopathy. Critical Reviews in Plant Sciences, 22(3-4), 367-389. https://doi.org/10.1080/713610861

Willis, R. J. (2007). The history of allelopathy (1st ed.). Australia: Springer Science \& Business Media.

\section{Copyrights}

Copyright for this article is retained by the author(s), with first publication rights granted to the journal.

This is an open-access article distributed under the terms and conditions of the Creative Commons Attribution license (http://creativecommons.org/licenses/by/4.0/). 